STUDI

FRANCESI

\section{Studi Francesi}

Rivista quadrimestrale fondata da Franco Simone

169 (LVII | I) | 2013

LA RÉVOLUTION SUR SCÈNE a cura di Pierre Frantz, Paola Perazzolo, Franco Piva

\title{
Annie Le Brun, Les Arcs-en-ciel du noir: Victor Hugo
}

\section{Lise Sabourin}

\section{OpenEdition}

Journals

Édition électronique

URL : http://journals.openedition.org/studifrancesi/3472

ISSN : 2427-5856

\section{Éditeur}

Rosenberg \& Sellier

\section{Édition imprimée}

Date de publication : 1 avril 2013

Pagination : 195

ISSN : 0039-2944

Référence électronique

Lise Sabourin, «Annie Le Brun, Les Arcs-en-ciel du noir: Victor Hugo », Studi Francesi [En ligne], 169 (LVII I

I) | 2013, mis en ligne le 30 novembre 2015, consulté le 17 septembre 2020. URL : http://

journals.openedition.org/studifrancesi/3472

Ce document a été généré automatiquement le 17 septembre 2020.

\section{cc) $(9)$}

Studi Francesi è distribuita con Licenza Creative Commons Attribuzione - Non commerciale - Non opere derivate 4.0 Internazionale. 


\title{
Annie Le Brun, Les Arcs-en-ciel du noir: Victor Hugo
}

\author{
Lise Sabourin
}

\section{RÉFÉRENCE}

ANNIE LE BRUN, Les Arcs-en-ciel du noir: Victor Hugo, Paris, Gallimard, 2011, «Art et artistes», pp. 145.

1 Ce livre résulte d'une exposition-carte blanche laissée à Annie Le Brun par le musée Victor Hugo de Paris et Hauteville House: invitée à puiser dans le fonds pour construire son itinéraire, elle a rédigé cet essai sur «l'encre, cette noirceur d'où sort une lumière» (pp. 7-10), déclinée en ténèbres comme répliques souterraines de l'arc-en-ciel chez Victor Hugo, à travers ses œuvres comme aux diverses époques de sa vie.

2 Noir donc «comme la jeunesse» (pp. 11-31), en ce temps du romantisme qui cultive Frankenstein et Melmoth pour plonger dans la nuit des temps, avec les motifs obsessionnels du gouffre et de l'échafaud, fasciné par l'ambivalence de l'excès. «Noir comme le théâtre des passions» (pp. 33-50), lorsque le théâtre et les amours s'allient comme une machine optique qu'imiteront la maison de poupée des enfants Hugo aussi bien que la «charrette-théâtre» de 1868 pour voir dans la nuit multiple. «Noir comme les voyages» (pp. 51-69), au temps des voyages avec Juliette, notamment sur le Rhin, qui permettent d'atteindre le rayonnement solaire par la toile métaphorique de l'araignée. «Noir comme la liberté» (pp. 71-91), par le combat déjà commencé avec Le Dernier Jour d'un condamné et continué dans l'exil avec Les Misérables. C'est bien «le choix du noir» (pp. 92-104) qui caractérise la quête hugolienne, en cette maison d'Hauteville House frénétiquement noircie en tous ses objets, collectionnés ou construits avec la fièvre d'un tourment qui ne s'autorise aucun vide. «Noir comme l'infini» (pp. 107-120) pour appréhender ce «trou de l'obscur» observé avec Arago en 1834 que Hugo continue à sonder toute sa vie, remontant «le cours de l'image pour voir de quoi elle est faite et d'où elle vient» (p. 116). «Noir comme l'éblouissement» (pp. 121-127) qu'il rêve toujours 
d'atteindre pour saisir l'arche de l'infini qui lui manque, avec toute l'audace et l'énormité de son lyrisme poétique. 